\title{
Tool surface with a supporting plateau of hard particles for deep drawing of high alloy steel
}

\author{
Hannes Freiße ${ }^{1, *}$ and Thomas Seefeld ${ }^{1}$ \\ ${ }^{1}$ BIAS - Bremer Institut für angewandte Strahltechnik GmbH, 28359 Bremen, Germany
}

\begin{abstract}
Sheet metal forming normally requires the application of lubricants to protect the tool and the sheet against wear. The parts must be cleaned to remove the lubricants before joining and coating. This process step wastes energy and water resources. In the case of non-lubricated sheet metal forming, cleaning processes would not be necessary anymore and the process chain could be optimized regarding ecological and economical aspects. However, forming without lubrication leads to an intensive contact between the tool and the sheet. Thus, higher wear occurs and process reliability cannot be ensured for industrial mass production. High alloy steels are applied for mass-market products e.g. for appliances. Because of the higher strength, strain hardening and galling effects the austenitic steels are comparatively difficult to form. For dry metal forming of high alloy steels new tool concept must be developed to withstand the higher loads. In this work, a laser generated tool surface with a supporting plateau of hard particles (metal matrix composite (MMC-surface)) is presented. Spherical fused tungsten carbides were injected into the surface by laser melt injection. The metallic matrix of the composite was rejected by applying laser ablation. In consequence, the hard particles stood out of the matrix and were in direct contact with the sheet material. The surface of hard particles had a high hardness about $3000 \mathrm{HV}$ and less metallic character. Cold working steel and aluminium bronze were tested as reference tool materials. Dry and lubricated forming experiments were carried out by strip drawing with bending and deep drawing of cups. Dry deep drawing of cups was not possible by using cold work tool steel. This can be traced back to the occurrence of wrinkles and cup base fracture at the same time. Applying aluminium bronze as tool material for dry metal forming resulted in high adhesive wear. Within this work the feasibility of dry metal forming of high alloy steel could be demonstrated by applying the MMC-surface whereby adhesive wear could be reduced.
\end{abstract}

Keywords: deep drawing, laser beam machining (LBM), metal matrix composite

\section{Introduction}

The high alloy steel (1.4301, X5CrNi18-10) is applied in industrial mass production e.g. in automotive industry or home appliance manufacturing because of the corrosion resistance and high fracture strain. This steel has metastable austenitic structure at room temperature. During forming the austenite can transform into martensite (TRIP-effect (Transformation Induced Plasticity)). An approach of calculating the martensite content depending on the strain is given in [1]. Because of the martensitic strain hardening, flow stress increase and higher forming forces are required [2]. The formation of martensite depends, among other, on the temperature [3]. In industrial forming processes the temperature may rise to $100{ }^{\circ} \mathrm{C}$ within the first 100 strokes [4]. Calculated heat transfer coefficient (HTC) of aluminium bronze and cold working tool steel against high alloy steel depending on the surface pressure are given in [5]. Aluminium bronze is a proofed tool material to form high alloy steel in lubricated deep drawing because of the high HTC [6].

However, to realize dry metal forming new tool concepts must be developed to withstand the higher loads [7]. In scientific investigations the surface condition before forming is rarely described, e.g. how the tools and sheets were cleaned which amount of residual contaminations were present on the surface [8].

Dry sliding of high alloy steel against tool steel 1.2379 resulted in high friction coefficients and adhesive wear [9]. In contrast, good results in dry deep drawing were achieved by applying ceramic tools [10]. Ceramics are expensive and add complexity to set-up. Furthermore, ceramics are brittle and particularly susceptible to cracking. Another approach to achieve a higher wear resistance is to reinforce the metallic surface with hard particles (metal matrix composite (MMC)) [11]. MMC combine the hardness and wear resistance of the particles with the ductility of the metal and can be generated e.g. by laser melt injection [12]. Investigations in strip

\footnotetext{
$\overline{\text { * Corresponding author: freisse@bias.de }}$
} 
drawing tests with bending revealed that MMC tool surfaces are suitable for lubricated sheet metal forming [13]. Literature presents only a few investigations on lubricated as well as in dry sheet metal forming by using MMC tool surfaces.

\section{Experimental Details}

\subsection{General}

Forming experiments were carried out by strip drawing with bending and deep drawing of cups. The description of the forming apparatus is given in [14].

In this work, three tool materials were applied. The MMC tool surface was made of aluminium bronze (CuAl10Ni5Fe4) reinforced with spherical fused tungsten carbides (SFTC)) with a particle content of MMC of about $50 \%$. Experimental details of reinforcing the surface with hard particles by laser melt injection and of producing a supporting plateau out of hard particles by ablation of the matrix using ultra short pulse laser are described in [15]. Two reference tool materials were tested: aluminium bronze (CuAl10Ni5Fe4) and cold working tool steel (1.2379). The workpiece sheet material was cold-rolled stainless steel 1.4301 with a sheet thickness of $0.5 \mathrm{~mm}$. The sheet surface was not textured and the roughness $\mathrm{Sa}$ was $0.35 \pm 0.01 \mu \mathrm{m}$. The hardness was $173 \pm 4 \mathrm{HV} 0.5$. Mechanical properties were determined in tensile tests according to DIN EN 10002-1 (Table 1 and Figure 1). The average of the normal anisotropy coefficient $\mathrm{R}$ was calculated by equation (1) and the planar anisotropy factor $R_{p}$ was calculated by equation (2). The average of the normal anisotropy coefficient was 1.21 and the planar anisotropy coefficient was -0.57 .

$$
\begin{aligned}
& R=\frac{1}{4} \cdot\left(R_{0}+2 \cdot R_{45}+R_{90}\right) \\
& R_{p}=\frac{1}{2} \cdot\left(R_{0}-2 \cdot R_{45}+R_{90}\right)
\end{aligned}
$$

Table 1. Mechanical properties of the sheet.

\begin{tabular}{|c|c|c|}
\hline \multirow{2}{*}{ property } & load direction & value \\
\hline \multirow{2}{*}{$\begin{array}{c}\text { tensile } \\
\text { strength }\end{array}$} & rolling direction $\left(0^{\circ}\right)$ & $729 \pm 1.1 \mathrm{MPa}$ \\
\cline { 2 - 3 } & diagonal direction $\left(45^{\circ}\right)$ & $663 \pm 1.5 \mathrm{MPa}$ \\
\cline { 2 - 3 } $\begin{array}{c}\text { yield } \\
\text { strength }\end{array}$ & transverse direction $\left(90^{\circ}\right)$ & $671 \pm 10.2 \mathrm{MPa}$ \\
\cline { 2 - 3 } & rolling direction $\left(0^{\circ}\right)$ & $281 \pm 0.9 \mathrm{MPa}$ \\
\cline { 2 - 3 } fracture & transvenal direction $\left(45^{\circ}\right)$ & $262 \pm 0.8 \mathrm{MPa}$ \\
\hline \multirow{2}{*}{ strain } & rolling direction $\left(90^{\circ}\right)$ & $264 \pm 5.9 \mathrm{MPa}$ \\
\cline { 2 - 3 }$\left(0^{\circ}\right)$ & $52 \pm 0.3 \%$ \\
\cline { 2 - 3 } $\begin{array}{c}\text { normal } \\
\text { anisotropy } \\
\text { coefficient }\end{array}$ & transonal direction $\left(45^{\circ}\right)$ & $60 \pm 0.8 \%$ \\
\cline { 2 - 3 } & diagonge direction $\left(90^{\circ}\right)$ & $60 \pm 1.9 \%$ \\
\cline { 2 - 3 } & transverse direction $\left(90^{\circ}\right)$ & $1.04 \pm 0.81 \pm 0.009$ \\
\hline
\end{tabular}

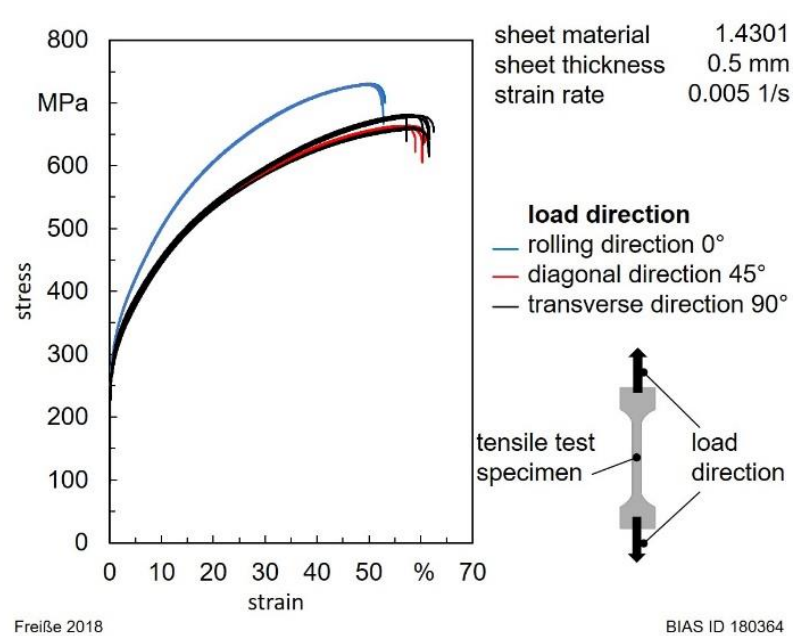

Fig. 1. Stress-strain diagram of the sheet metal

To investigate the behaviour for dry metal forming the sheets and the tools were cleaned in an ultrasonic bath with $10 \%$ solution of Tickopur R33 cleaning agent for 10 minutes. Afterwards, the parts were rinsed with deionized water, submerged in pure ethanol for 5 seconds and dried with a fan.

At first all dry forming experiments and thereafter all lubricated experiments were carried out with the same tool. The tools were not removed and mounted again between the dry and lubricated experiments to avoid assembly-related influences. In each case three parts were formed. The maximum forming forces were measured, the average and the standard deviation were investigated.

The surface roughness Sa was measured according to EN ISO 25178 with a measurement area of $200 \times 200 \mu \mathrm{m}^{2}$ using 3D laser scanning confocal microscope Keyence VK-9700 with a magnification of 50x. The low-pass filter (S-filter) was adjusted to $0.5 \mu \mathrm{m}$ (lowest value) and the high-pass filter (L-filter) was set to $0.2 \mathrm{~mm}$ (edge length of the measurement field).

\subsection{Strip drawing with bending}

A sketch of strip drawing with bending is depicted in Figure 2. The tools were machined by wire cut electrical discharge machining (EDM). The punch diameter was $\varnothing 30 \mathrm{~mm}$ and the punch radius was $4 \mathrm{~mm}$. The sheets were of $52 \times 20 \mathrm{~mm}^{2}$ and were cut in rolling direction $\left(0^{\circ}\right)$.

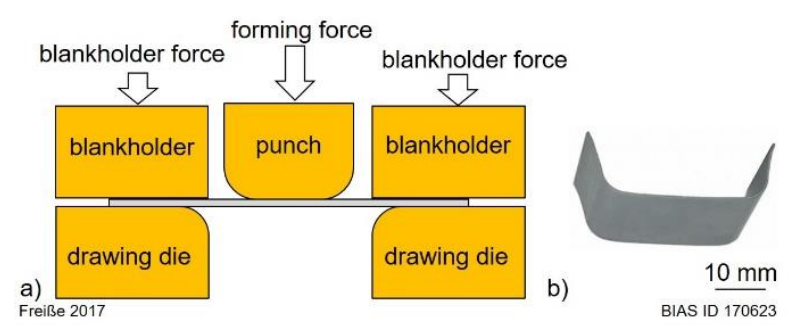

Fig. 2. a) Sketch of strip drawing with bending, b) bended strip as a U-shaped component.

A strip drawing die with MMC surface is shown in Figure 3. After EDM machining, the surface roughness Sa amounted to $0.75 \pm 0.04 \mu \mathrm{m}$. Pores were visible in the 
MMC surface which resulted from the process of laser melt injection. At first forming experiments were performed without depression. Afterwards the surfaces were laser ablated and a depression of $5 \mu \mathrm{m}$ was set.

Forming experiments were carried out by variation of the drawing radius (from $5 \mathrm{~mm}$ to $7 \mathrm{~mm}$ ) and two different initial blankholder pressures were applied (1.6 MPa and 3.2 $\mathrm{MPa})$.

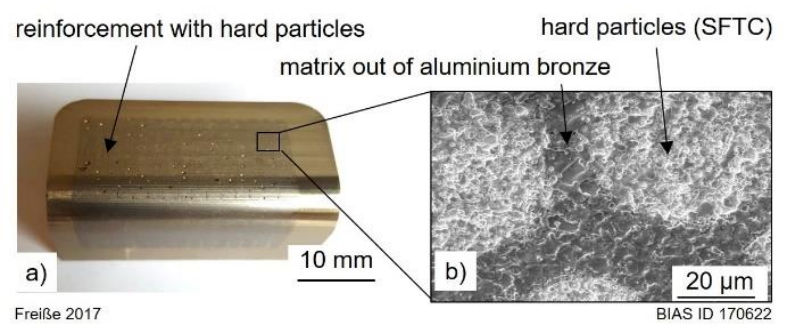

Fig. 3. a) drawing die reinforced with hard particles machined by wire electrical discharge machining (EDM), b) scanning electron microscope (SEM) image of the surface.

The tools of aluminium bronze and cold working tool steel were hardened. The roughness $\mathrm{Sa}$ of the bronze surface amounted to $0.36 \pm 0.05 \mu \mathrm{m}$ and of the steel surface was $0.45 \pm 0.03 \mu \mathrm{m}$. Forming experiments were carried out by variation of the drawing radius $(3 \mathrm{~mm}$ to $7 \mathrm{~mm})$, by variation of the drawing clearance $(0.7 \mathrm{~mm}$ to $1.5 \mathrm{~mm}$ ) and two different initial blankholder pressure were applied (1.6 MPa and 3.2 MPa).

\subsection{Deep drawing of cups}

Details of the experimental set-up are given in [14]. The die radius was $4 \mathrm{~mm}$. The initial blankholder pressure was 3.2 MPa. Drawing dies were tested with a MMC surface, aluminium bronze and cold working steel (Table 2). Eight tools were applied: three tools with a drawing clearance of $0.7 \mathrm{~mm}$ and five tools with a drawing clearance of $1 \mathrm{~mm}$. The tools were machined by milling and die-sinking electrical discharge machining (EDM).

Table 2. Material, manufacturing process and drawing clearance of the drawing dies.

\begin{tabular}{|c|c|c|c|}
\hline tool no. & material & machined & $\begin{array}{l}\text { drawing } \\
\text { clearance }\end{array}$ \\
\hline 1 & \multirow{4}{*}{ bronze } & \multirow{5}{*}{ milled } & \multirow{2}{*}{$0.7 \mathrm{~mm}$} \\
\hline 2 & & & \\
\hline 3 & & & \multirow{2}{*}{$1 \mathrm{~mm}$} \\
\hline 4 & & & \\
\hline 5 & steel & & $0.7 \mathrm{~mm}$ \\
\hline 6 & bronze & \multirow{3}{*}{$\begin{array}{l}\text { die-sinking } \\
\text { EDM }\end{array}$} & \multirow{3}{*}{$1 \mathrm{~mm}$} \\
\hline 7 & \multirow{2}{*}{ MMC } & & \\
\hline 8 & & & \\
\hline
\end{tabular}

Dry and lubricated forming was performed (3 sheets each) and afterwards the tools were removed, cleaned and the set of experiments (dry and lubricated) was repeated one more time. The maximum drawing ratio in dry metal forming was investigated by varying the blank diameter and using bronze tool 3 .

The milled drawing diess out of steel had a surface roughness Sa of $0.3 \pm 0.03 \mu \mathrm{m}$ and the milled drawing dies out of bronze had a surface roughness Sa of $0.6 \pm 0.02$ $\mu \mathrm{m}$.

The micro geometry of the MMC surface produced by die sinking electrical discharge machining (EDM) differed significantly from the wire cut EDM machined surface of the tools for strip drawing with bending. No plane surface was produced by die sinking EDM (see Figure 4). The aluminium bronze matrix was removed stronger. The depression varied between $20 \mu \mathrm{m}$ and $100 \mu \mathrm{m}$. The wire cutting resulted in uneven removal of the surface, where removal of the matrix material was more pronounced than of the hard particles, see Figure 4. The height difference was 20-100 $\mu \mathrm{m}$.
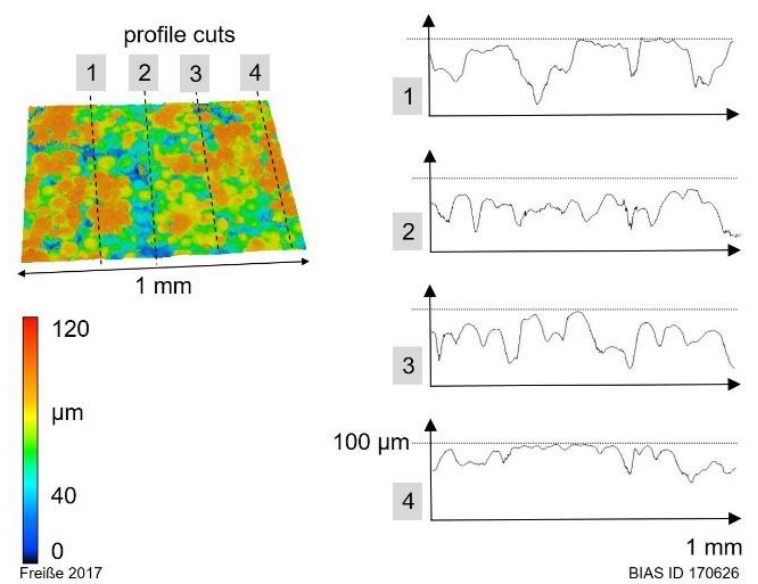

Fig. 4. 3D laser scanning confocal microscope image and profile cuts of the MMC surface machined by die-sinking electrical discharge machining (EDM).

\subsection{Calculated true blankholder pressure}

The initial blankholder force was 3.2 MPa for this particular calculation. The blankholder force was kept constant and the parts were completely drawn in. So, the area under the blankholder decreased and the true blankholder pressure tended towards infinity. Exemplarily calculated blankholder pressures up to a sheet draw-in of $11 \mathrm{~mm}$ are depicted in Figure 5. The larger the drawing radius and the wider the drawing clearance, the earlier was the increase of the true blankholder pressure.
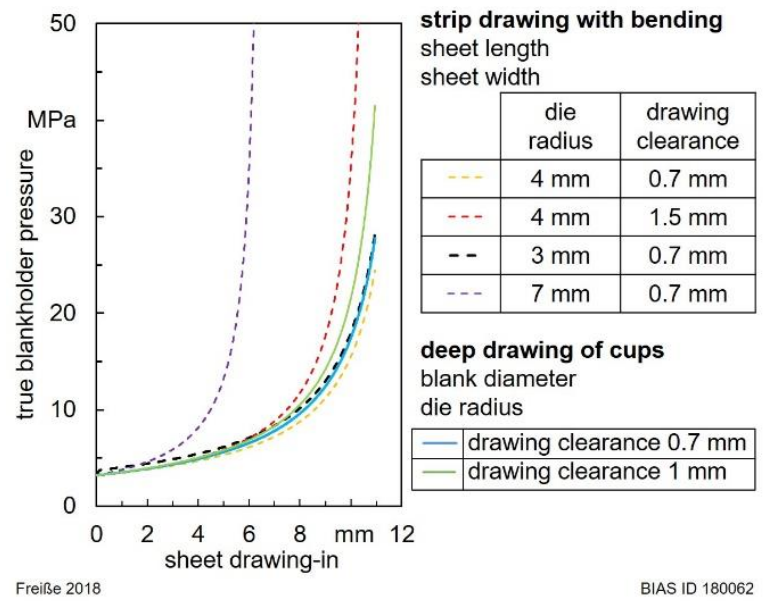

Fig. 5. Example on calculated blankholder pressures up to a sheet draw-in of $11 \mathrm{~mm}$. 
Furthermore, the amount of sheet under the blankholder depends on the die geometry. The smallest sheet drawingin of $6.6 \mathrm{~mm}$ occured in strip drawing when bending with a die radius of $7 \mathrm{~mm}$ and whereas the largest drawing-in of $12.6 \mathrm{~mm}$ occurred when bending with a die radius of $3 \mathrm{~mm}$.

\section{Results}

\subsection{Strip drawing with bending}

\subsubsection{Reference tool materials}

The influence of the drawing clearance on the forming force by using bronze tool is shown in Figure 6 and by using steel tool is shown in Figure 7.

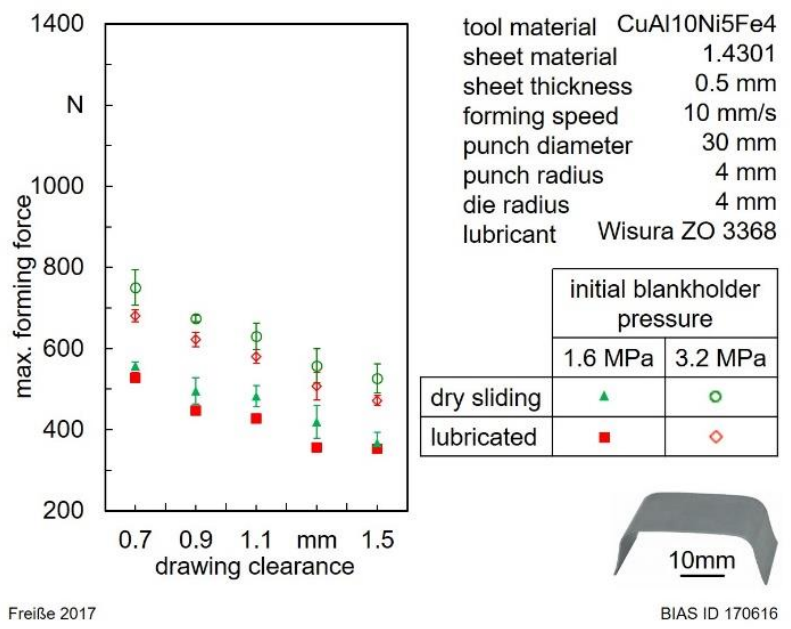

Fig. 6. Max. forming forces using bronze tool under variation of the drawing clearance.

No significant influence of the tool material was investigated even in dry forming. The forming forces fluctuated between $353 \mathrm{~N}$ and $800 \mathrm{~N}$. Applying either lubrication or smaller drawing clearance or lower blankholder pressure resulted in lower forming forces.
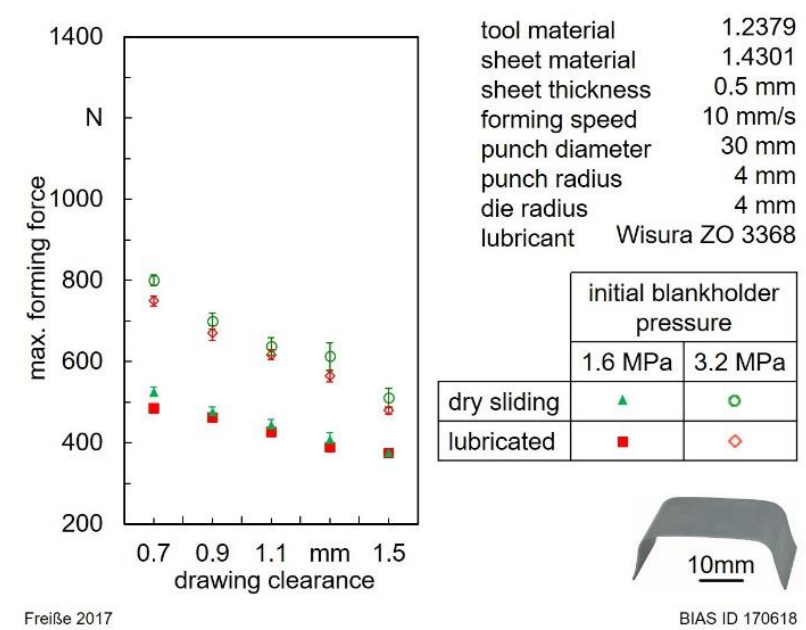

Fig. 7. Max. forming forces using steel tool under variation of the drawing clearance.
A significance analysis was carried out for each experimental variation: increasing the initial blankholder pressure, forming without lubrication and reducing the drawing clearance.

For calculating the impact factor on the increased forming force by higher initial blankholder pressure and forming without lubrication, at first the ratio between the high and low max. forming force for each drawing clearance was determined. E.g. the influence factor for increasing the initial blankholder pressure for a drawing clearance of $0.7 \mathrm{~mm}$ by using steel tool (Fig. 7), the ratio in dry sliding was calculated by: $800 \mathrm{~N} / 525 \mathrm{~N}=1.52$ and the ratio for lubricated sliding was calculated by: 749 $\mathrm{N} / 485 \mathrm{~N}=1.54 \mathrm{~N}$. Thereafter, the averages and standard deviations of these ratios for all drawing clearances were calculated $(1.45 \pm 0.07)$.

E.g. the influence factor for forming without lubrication for a drawing clearance of $0.7 \mathrm{~mm}$ by using steel tool (Fig. 7), the ratio for forming by using a low initial blankholder pressure was calculated by: $525 \mathrm{~N} / 485 \mathrm{~N}=1.08$ and the ratio for forming by using a high initial blankholder pressure was calculated by: $800 \mathrm{~N} / 749 \mathrm{~N}=1.07$. Thereafter, the averages and standard deviations of these ratios for all drawing clearances were calculated $(1.05 \pm 0.02)$.

Increasing the initial blankholder pressure had a higher influence compared to forming without lubrication (Table 3).

Table 3. Factors for increasing the forming forces in the case of using bronze tool and steel tool.

\begin{tabular}{|r|c|c|}
\hline variation & bronze tool & steel tool \\
\hline $\begin{array}{r}\text { increasing the initial } \\
\text { blankholder pressure }\end{array}$ & $1.36 \pm 0.05$ & $1.45 \pm 0.07$ \\
\hline without lubrication & $1.10 \pm 0.04$ & $1.05 \pm 0.02$ \\
\hline
\end{tabular}

The significance analysis of variation the drawing clearance was carried out by a linear regression analysis. The results of the linear regression analyse in the case of using bronze tool is given in Table 4 and in the case of using steel tool is given in Table 5. The influence of the drawing clearance was higher in the case of higher initial blankholder pressure. The slopes of the regression were slightly higher in the case of forming without lubrication.

Table 4. Regression analysis of variation of the drawing clearance in the case of using bronze tool

\begin{tabular}{|c|c|c|c|}
\hline \multirow{2}{*}{ lubrication } & $\begin{array}{c}\text { initial } \\
\text { blankholder } \\
\text { pressure }\end{array}$ & $\begin{array}{c}\text { slope of } \\
\text { the } \\
\text { regression }\end{array}$ & $\begin{array}{c}\text { determination } \\
\text { coefficient } \mathbf{R}^{\mathbf{2}}\end{array}$ \\
\cline { 1 - 1 } with & \multirow{2}{*}{$1.6 \mathrm{MPa}$} & $\begin{array}{c}\mathrm{y}=-44.2 \mathrm{x} \\
+554.9\end{array}$ & 0.923 \\
\cline { 4 - 5 } without & \multirow{2}{*}{ with } & $\begin{array}{c}\mathrm{y}=-45.7 \mathrm{x} \\
+601.3\end{array}$ & 0.973 \\
\cline { 1 - 1 } without & \multirow{2}{*}{$3.2 \mathrm{MPa}$} & $\begin{array}{c}\mathrm{y}=-53.2 \mathrm{x} \\
+731.9\end{array}$ & 0.991 \\
\cline { 3 - 4 } & & $\begin{array}{c}\mathrm{y}=-56.4 \mathrm{x} \\
+796.8\end{array}$ & 0.984 \\
\hline
\end{tabular}


Table 5. Regression analysis of variation of the drawing clearance in the case of using steel tool

\begin{tabular}{|c|c|c|c|}
\hline lubrication & $\begin{array}{c}\text { initial } \\
\text { blankholder } \\
\text { pressure }\end{array}$ & $\begin{array}{c}\text { slope of } \\
\text { the } \\
\text { regression }\end{array}$ & $\begin{array}{c}\text { determination } \\
\text { coefficient } \mathbf{R}^{\mathbf{2}}\end{array}$ \\
\cline { 1 - 2 } with & \multirow{2}{*}{$1.6 \mathrm{MPa}$} & $\begin{array}{c}\mathrm{y}=-26.6 \mathrm{x} \\
+515.7\end{array}$ & 0.986 \\
\cline { 3 - 4 } without & $\begin{array}{c}\mathrm{y}=-36.7 \mathrm{x} \\
+555.9\end{array}$ & 0.993 \\
\hline \multirow{2}{*}{ with } & \multirow{2}{*}{$3.2 \mathrm{MPa}$} & $\begin{array}{c}\mathrm{y}=-64.6 \mathrm{x} \\
+809.5\end{array}$ & 0.992 \\
\cline { 4 - 4 } without & $\begin{array}{c}\mathrm{y}=-66.6 \mathrm{x} \\
+851.47\end{array}$ & 0.964 \\
\hline
\end{tabular}

The maximum forming forces under variation of the drawing radius using bronze tool are shown in Figure 8 and for the steel tool in Fig. 9.
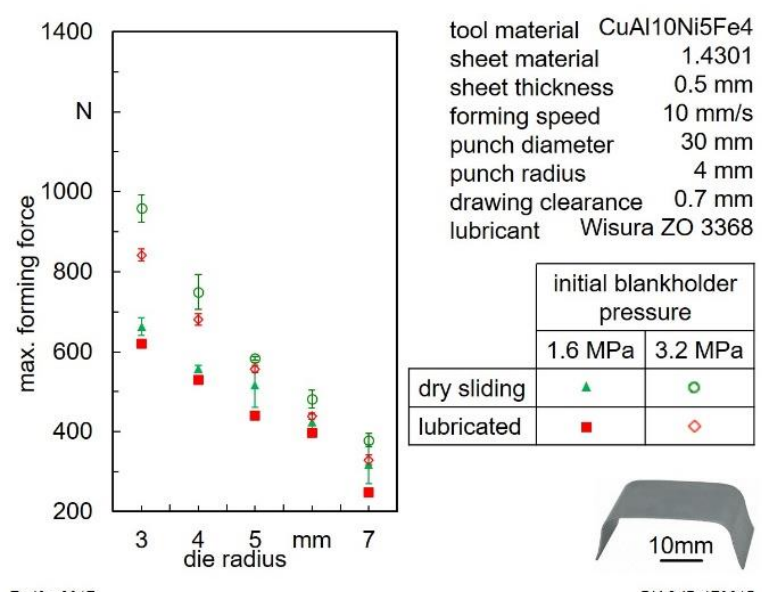

Fig. 8. Max. forming forces using bronze tool under variation of the drawing radius.

The forces were slightly higher in the case of using steel tool with smaller drawing radius compared to bronze tool. Forming forces from $247 \mathrm{~N}$ to $1058 \mathrm{~N}$ were measured. The forces were lower in the case of lubricated forming compared to dry metal forming. By applying higher blankholder pressure the forming forces were increased. Forming with smaller drawing radius resulted in higher forming force.

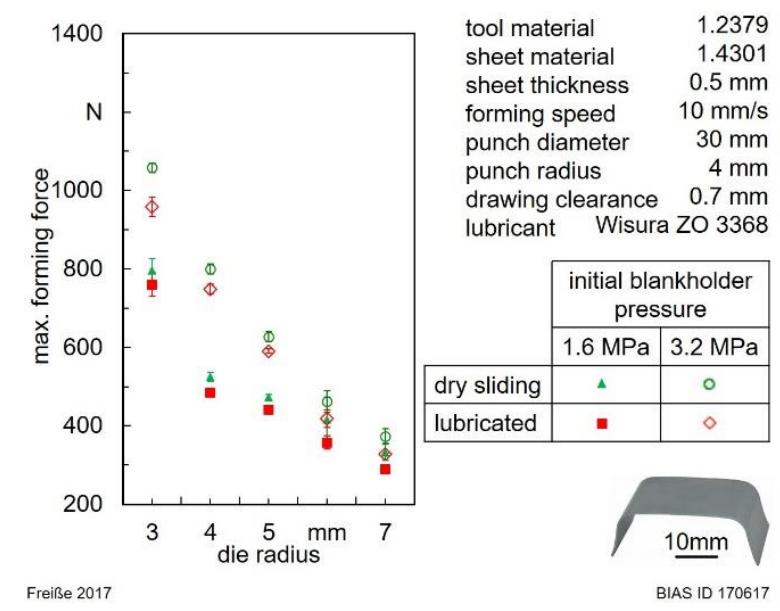

Fig. 9. Max. forming forces using steel tool under variation of the drawing radius.
The main influence factor increasing the forming force was increasing the initial blankholder pressure (Table 6). The lowest impact on the forming forces was determined by dry forming.

Table 6. Factors for increasing the forming forces in the case of using bronze tool and steel tool.

\begin{tabular}{|r|c|c|}
\hline variation & bronze tool & steel tool \\
\hline $\begin{array}{r}\text { increasing the initial } \\
\text { blankholder pressure }\end{array}$ & $1.25 \pm 0.1$ & $1.28 \pm 0.15$ \\
\hline without lubrication & $1.19 \pm 0.06$ & $1.10 \pm 0.04$ \\
\hline
\end{tabular}

The linear regression analysis of variation the drawing radius in the case of using bronze tool is given in Table 7 and in the case of using steel tool is given in Table 8 . The influence of the drawing radius was higher in the case of higher initial blankholder pressure. It is remarkable that the slope of the regression was lower by forming without lubrication in the case of lower initial blankholder pressure for both tool materials. Furthermore, the influence of the drawing radius was higher when steel was used as tool material.

Table 7. Regression analysis of variation of the drawing radius in the case of using bronze tool.

\begin{tabular}{|c|c|c|c|}
\hline lubrication & $\begin{array}{c}\text { initial } \\
\text { blankholder } \\
\text { pressure }\end{array}$ & $\begin{array}{l}\text { slope of } \\
\text { the } \\
\text { regression }\end{array}$ & $\begin{array}{l}\text { determination } \\
\text { coefficient } R^{2}\end{array}$ \\
\hline with & \multirow{2}{*}{$1.6 \mathrm{MPa}$} & $\begin{array}{c}y=-87.9 x \\
+710.2\end{array}$ & 0.974 \\
\hline without & & $\begin{array}{c}y=-82.1 x \\
+742.43\end{array}$ & 0.983 \\
\hline with & \multirow{2}{*}{$3.2 \mathrm{MPa}$} & $\begin{array}{c}y=- \\
126.7 \mathrm{x} \\
+949.4\end{array}$ & 0.994 \\
\hline without & & $\begin{array}{c}y=- \\
142.8 \mathrm{x} \\
+1058.9\end{array}$ & 0.973 \\
\hline
\end{tabular}

Table 8. Regression analysis of variation of the drawing radius in the case of using steel tool.

\begin{tabular}{|c|c|c|c|}
\hline lubrication & $\begin{array}{c}\text { initial } \\
\text { blankholder } \\
\text { pressure }\end{array}$ & $\begin{array}{l}\text { slope of } \\
\text { the } \\
\text { regression }\end{array}$ & $\begin{array}{l}\text { determination } \\
\text { coefficient } \mathbf{R}^{2}\end{array}$ \\
\hline with & \multirow{2}{*}{$1.6 \mathrm{MPa}$} & $\begin{array}{c}\mathrm{y}=- \\
107.1 \mathrm{x} \\
+787.9\end{array}$ & 0.878 \\
\hline without & & $\begin{array}{c}y=- \\
103.6 x \\
+819.9\end{array}$ & 0.867 \\
\hline with & \multirow{2}{*}{$3.2 \mathrm{MPa}$} & $\begin{array}{c}y=- \\
159.1 x \\
+1086\end{array}$ & 0.984 \\
\hline without & & $\begin{array}{c}y=- \\
170.6 x \\
+1176\end{array}$ & 0.97 \\
\hline
\end{tabular}




\subsubsection{MMC tool}

In Figure 10 the forming forces are shown in the case of using MMC tool without depression. Forming forces from $365 \mathrm{~N}$ to $1130 \mathrm{~N}$ were measured. The results of the forming tests by applying the MMC tool surface with a depression of $5 \mu \mathrm{m}$ are depicted in Figure 11.

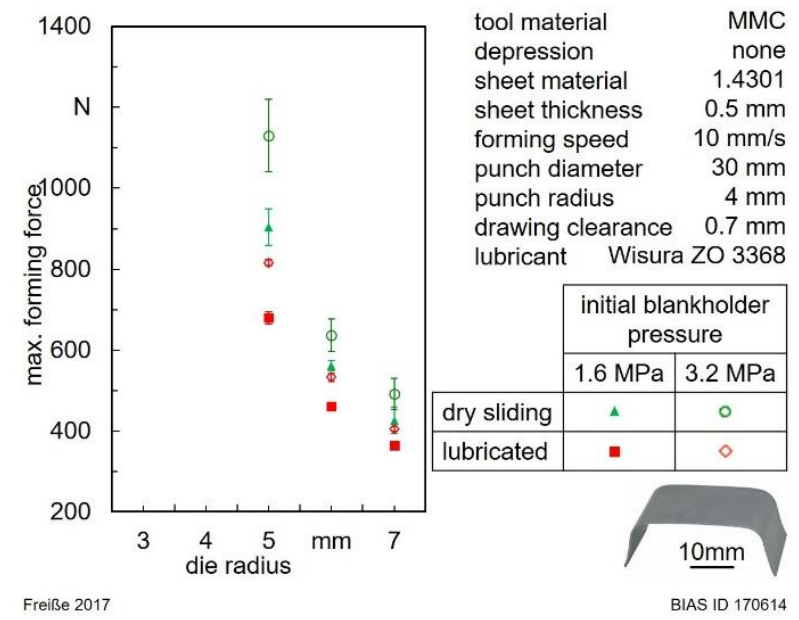

Fig. 10. Max. forming forces using MMC tool without depression.

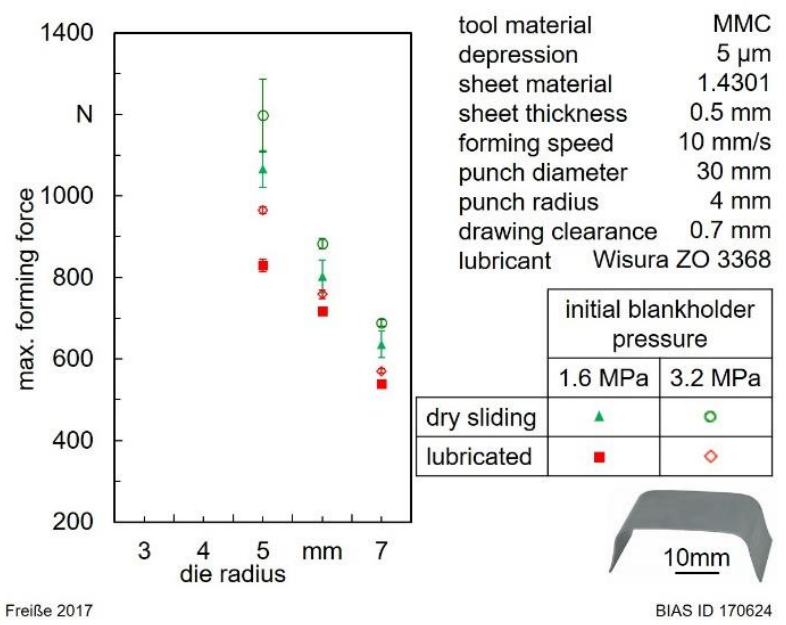

Fig. 11. Max. forming forces using MMC tool with $5 \mu \mathrm{m}$ depression.

The values of the forming forces varied between $536 \mathrm{~N}$ and $1197 \mathrm{~N}$. The forces increased when using smaller drawing radius, higher blankholder pressure and no lubrication. These effects can be observed by applying the MMC tool surface without as well as with a supporting plateau of hard particles.

Factors for increasing the forming forces by variation in the case of using MMC tool surface with and without lubrication are given in Table 9. The lowest impact on the forming force resulted by applying higher blankholder pressure. The influence of forming without lubrication had higher influence on the forming force compared to the increased initial blankholder pressure. Particularly, using a MMC surface with depression led to lower impact of the increased initial blankholder pressure and avoidance of lubrication on the forming force.
Table 9. Factors for increasing the forming forces in the case of using MMC tool surface.

\begin{tabular}{|r|c|c|}
\hline variation & $\begin{array}{c}\text { without } \\
\text { depression }\end{array}$ & $\begin{array}{c}\mathbf{5} \boldsymbol{\mu m} \\
\text { depression }\end{array}$ \\
\hline $\begin{array}{r}\text { increasing initial } \\
\text { blankholder pressure }\end{array}$ & $1.17 \pm 0.04$ & $1.09 \pm 0.03$ \\
\hline without lubrication & $1.25 \pm 0.08$ & $1.20 \pm 0.05$ \\
\hline
\end{tabular}

The results of the linear regression analysis of variation the drawing radius in the case of using MMC tool without depression is given in Table 10 and in the case of using MMC tool with depression is given in Table 11.

Table 10. Regression analysis of variation of the drawing radius in the case of using MMC tool without depression.

\begin{tabular}{|c|c|c|c|}
\hline lubrication & $\begin{array}{c}\text { initial } \\
\text { blankholder } \\
\text { pressure }\end{array}$ & $\begin{array}{c}\text { slope of } \\
\text { the } \\
\text { regression }\end{array}$ & $\begin{array}{l}\text { determination } \\
\text { coefficient } \mathbf{R}^{2}\end{array}$ \\
\hline with & \multirow{2}{*}{$1.6 \mathrm{MPa}$} & $\begin{array}{c}y=- \\
157.4 \mathrm{x} \\
+1131.2\end{array}$ & 0.951 \\
\hline without & & $\begin{array}{c}y=- \\
238.8 x \\
+1585.5\end{array}$ & 0.941 \\
\hline with & \multirow{2}{*}{$3.2 \mathrm{MPa}$} & $\begin{array}{c}y=- \\
205.5 x \\
+1406.8\end{array}$ & 0.955 \\
\hline without & & $\begin{array}{c}y=- \\
319.4 x \\
+2030.3\end{array}$ & 0.909 \\
\hline
\end{tabular}

Table 11. Regression analysis of variation of the drawing radius in the case of using MMC tool with depression.

\begin{tabular}{|c|c|c|c|}
\hline lubrication & $\begin{array}{c}\text { initial } \\
\text { blankholder } \\
\text { pressure } \\
\end{array}$ & $\begin{array}{c}\text { slope of } \\
\text { the } \\
\text { regression }\end{array}$ & $\begin{array}{l}\text { determination } \\
\text { coefficient } R^{2}\end{array}$ \\
\hline with & \multirow{2}{*}{$1.6 \mathrm{MPa}$} & $\begin{array}{l}y=-145 x \\
+1275.7\end{array}$ & 0.983 \\
\hline without & & $\begin{array}{l}y=-215 x \\
+1695.1\end{array}$ & 0.984 \\
\hline with & \multirow{2}{*}{$3.2 \mathrm{MPa}$} & $\begin{array}{c}y=- \\
197.2 x \\
+1553.2\end{array}$ & 0.999 \\
\hline without & & $\begin{array}{c}y=- \\
254.4 x \\
+1940.5\end{array}$ & 0.982 \\
\hline
\end{tabular}

The slope of the regression was increased either by applying higher initial blankholder pressure or by forming without lubrication. It is remarkable that the influence of the drawing radius on the forming force was lower by using MMC with depression in the case of higher initial blankholder pressure.

\subsection{Deep drawing of cups}

\subsubsection{Milled tools}

In Figure 12 the deep drawing forces are shown by using two tools in each case with a drawing clearance of 
$0.7 \mathrm{~mm}$ and $1 \mathrm{~mm}$. The deep drawing forces were lowered about $15 \%$ by applying higher drawing clearance in the case of lubricated deep drawing. A reproducibility of the lubricated forming results could be achieved by applying different tools. In contrast, in dry metal forming there were high deviations between the results of applying different tools with the same drawing clearance. On the average, the forces were lower in the case of applying higher drawing clearance. Significant higher standard deviations of the forming forces were found in the case of dry metal forming.

The experiments were repeated with the tool 3 and 4 (Figure 13). The tools were removed, cleaned and mounted again. The deep drawing forces were reproducible in the case of lubricated forming.

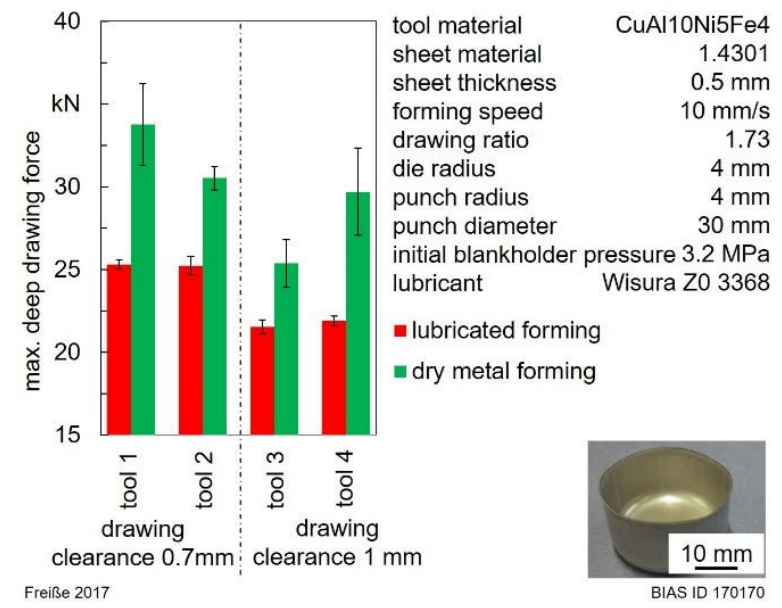

Fig. 12. Max. deep drawing forces using milled bronze tool under variation of the drawing clearance.

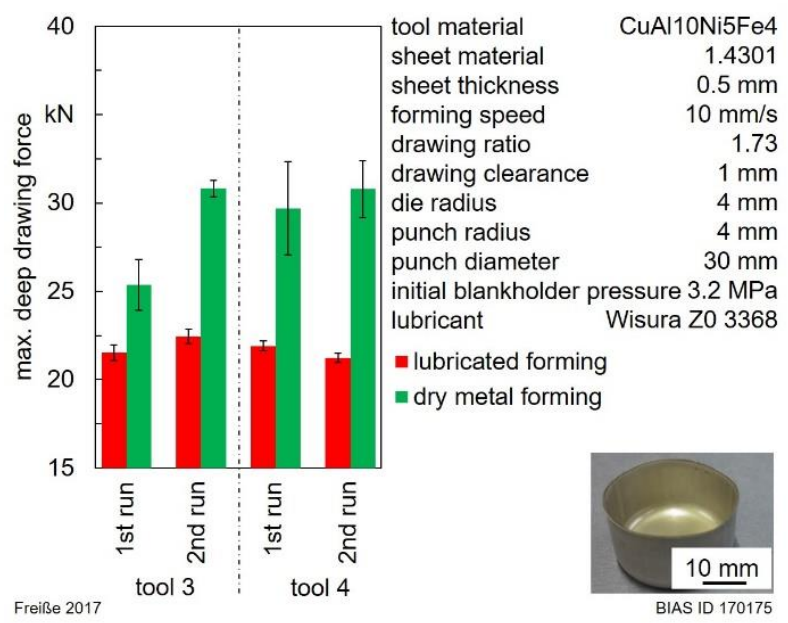

Fig. 13. Max. deep drawing forces using milled bronze tool by repeated forming tests.

The highest difference was about $4 \%$ by using tool 3 . However, the results differ strongly in the case of dry metal forming. The highest difference was about $22 \%$ by using tool 3.

By forming different blank diameters from $52 \mathrm{~mm}$ to $62 \mathrm{~mm}$ and using bronze tool 3 , the drawing ratio was varied from 1.73 to 2.07 . In dry metal forming, a maximum drawing ratio of 1.93 was investigated (Figure 14). Using larger blank diameter than $58 \mathrm{~mm}$ in dry metal forming resulted in cup base fractures. By reducing the initial blankholder pressure, the simultaneous occurrence of cup base fracture and wrinkles formation of first order was observed which was an indication for the process limit in dry metal forming.

Blank diameter of $62 \mathrm{~mm}$ could be formed in lubricated deep drawing. Larger diameters could not be applied because of geometric circumstances of the deep drawing apparatus.

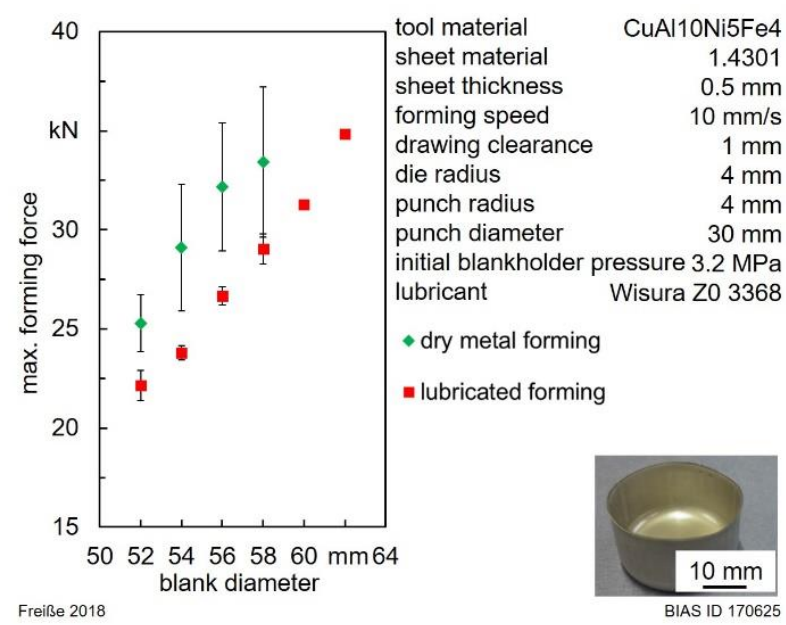

Fig. 14. Max. deep drawing forces using milled bronze tool under variation of the blank diameter using bronze tool 3 .

The max. forming forces in lubricated forming by using steel tool were comparable to those in the case of using bronze tool. Dry metal forming by using steel tool was not possible. Applying a blankholder pressure of $3.2 \mathrm{MPa}$ resulted in cup base fracture. When the blankholder pressure was reduced to $2.8 \mathrm{MPa}$, wrinkle formation of the first order and cup base fracture occurred at the same time (Figure 15).

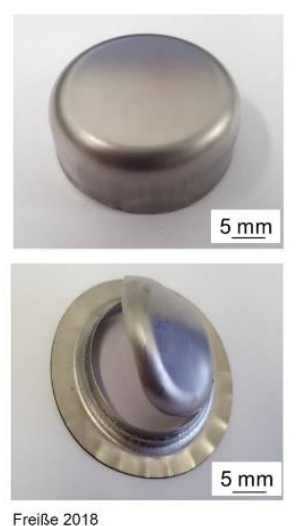

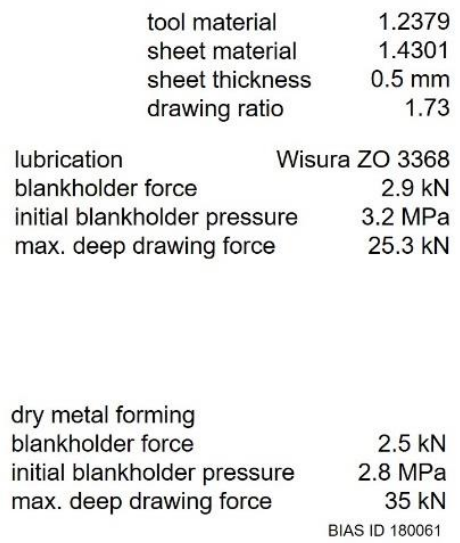

Fig. 15. Deep drawing by using tool out of tool steel and a drawing clearance of $0.7 \mathrm{~mm}$.

\subsubsection{EDM tools}

In Figure 16 the max. forming forces are shown by using tools machined by die-sinking EDM out of bronze and MMC. The forming forces by using the EDMmachined bronze tool were about $20 \%$ lower compared to the forming forces investigated by using the milled bronze 
tool. Dry metal forming led to higher forming forces compared to lubricated forming. The forces were higher by applying the MMC tools. Two MMC tools were tested and a reproducible result could be achieved.

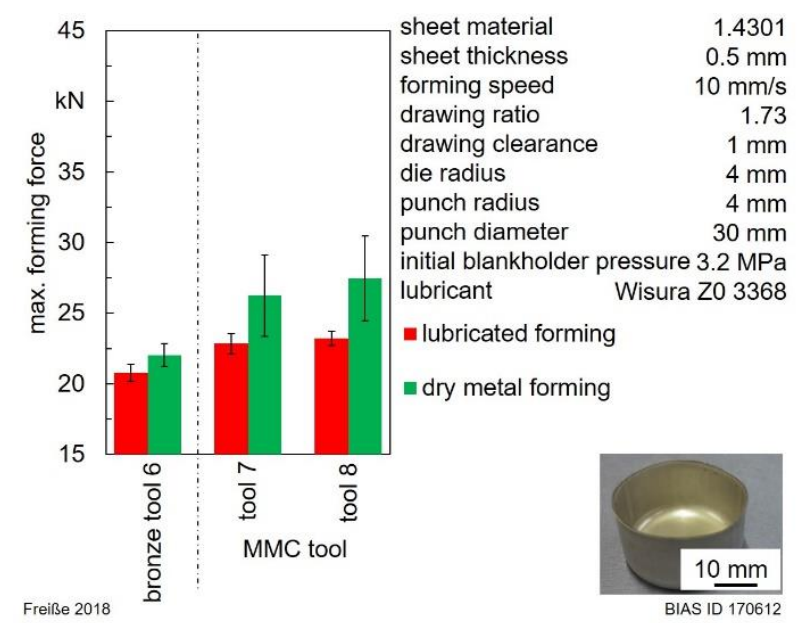

Fig. 16. Max. forming forces using tools machined by die-sinking EDM.

The formed cups were analysed by EDX (Electron Diffraction X-Ray) analysis (Figure 17). Adhesive wear was determined. This can be traced back to the detected copper $(\mathrm{Cu})$ from the tool on the steel sheet $(\mathrm{Fe})$. The adhesive wear could be significantly reduced by applying the MMC tool. However, more scoring occurred when MMC acted as tool material. It is assumed that the particles penetrated the sheet material and caused the scoring. The anisotropic properties of the cold rolled sheet led to earing at the cups. Exemplarily hardness measurement revealed that the hardness in the sheet was increased up to $360 \mathrm{HV} 0.5$. The cups became magnetic which can be traced back to the formation of martensite.

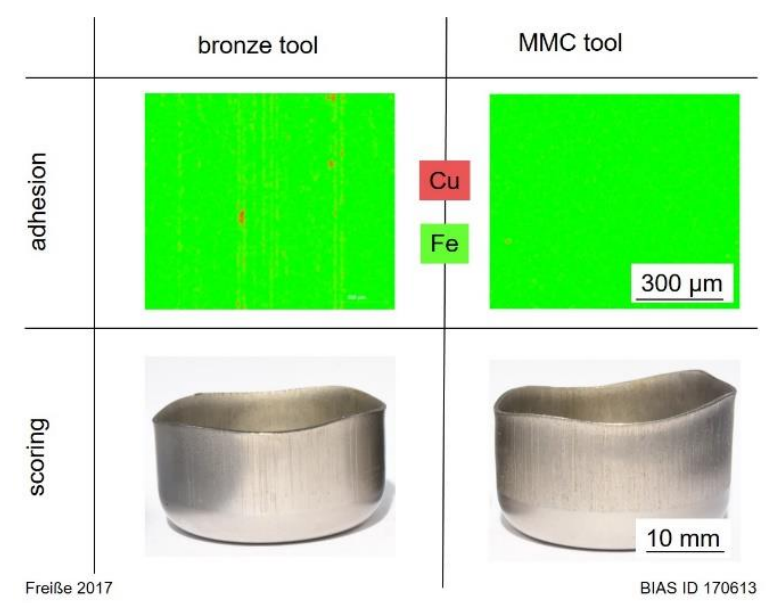

Fig. 17. Adhesive and abrasive wear in the deep drawn cups using bronze tool with and without hard particles.

\section{Discussion}

Sheet forming experiments were carried out by variation of the drawing clearance and drawing radius to investigate the influence on the forming force. Lower drawing clearances [16] and smaller drawing radius [17] lead to higher forming forces. This could be confirmed in this work by strip drawing with bending and deep drawing of cups. The deep drawing forces were about $15 \%$ lower in lubricated deep drawing of cups by increasing the drawing clearance from $0.7 \mathrm{~mm}$ to $1 \mathrm{~mm}$. This is comparable to the results of strip drawing with bending. By using a regression analyse of the results of strip drawing with bending, it could be shown that the influence of the drawing radius was significantly higher compared to the influence of the drawing clearance on the forming force. Furthermore, the influence of the drawing radius as well as the influence of the drawing clearance was higher in all experiments in strip drawing with bending when the initial blankholder pressure was increased.

Dry deep drawing of cups could be carried out by using the reference tool material bronze. There was a high difference of the forming forces in the case of dry metal forming when two different tools with the same geometry were applied. It was assumed that this was caused by production-related tolerances of the drawing dies. However, by using the same tool after removing, cleaning and mounting again the forming forces differed in dry metal forming. This may be traced back to assemblyrelated tolerances. However, there was no impact of production-related and assembly-related influences in lubricated forming.

In this work, lubricated forming by using tool steel led to comparable forming force to those by using bronze tool. However, dry forming with steel tool resulted in cup base fracture and wrinkle formation. So, there was no influence of the tool material in lubricated forming but a high influence of the tool material in dry deep drawing of cups. This agrees with the results of strip drawing without bending in previous work [18]. Bronze showed low friction coefficient against high alloy steel even at higher blankholder pressure. Dry sliding using tool steel led to high friction coefficient and adhesive wear even at low contact pressure. In contrast, in this work the forming forces were in some cases higher in strip drawing test with bending when bronze was used as tool material. However, slightly higher forming forces resulted when cold working tool steel was applied as tool material. The factor by which the forces were higher in the case of steel tool amounted to $1.04 \pm 0.05$. This was not influenced by variation of the drawing radius nor of the drawing clearance. It can be concluded that the results of the strip drawing with bending cannot be compared with results of strip drawing without bending or with the results of forming cups.

Avoiding lubrication increased the forming forces by $5 \%$ to $19 \%$ in strip drawing with bending using the reference tool materials. By using the MMC surface in strip drawing with bending the forming forces were increased from $22 \%$ to $23 \%$ by avoiding lubrication even in the case the surface had no depression. It is assumed that this was caused by the different tool properties in the composite material. The Young's modulus of the spherical tungsten carbide [19] is about five times higher compared to the Young's modulus of the aluminium bronze [20]. It is assumed that the matrix of the MMC was slightly impressed when high contact pressure occurred 
during forming particularly under the blankholder. In consequence the particles stood out of the surface and penetrated in the sheet material. This acted as a mechanical hindrance to the movement and higher forming forces were investigated. By the regression analysis it could be shown that ablation the matrix by $5 \mu \mathrm{m}$ and using a plateau of hard particles had no significant influence on the forming forces. Furthermore, in deep drawing of cups with higher penetrations of $20 \mu \mathrm{m}$ to $100 \mu \mathrm{m}$ in the die-sinking EDM-machined MMC surface showed the same difference of dry forming to lubricated of around $22 \%$. So, higher penetrations do not significantly influence the forming forces. It was shown that adhesive wear could be reduced by using MMC surface with higher penetration for deep drawing of cups. It is assumed that the high penetration reduced the contact area between the sheet and the bronze matrix. However, using penetration in MMC surface lead to scoring in the cup surface even in lubricated sliding. This agrees with the results of previous work by applying strip drawing without bending. The scoring effect occurred particularly at high contact pressure [18].

\section{Conclusion}

Dry metal forming of high alloy steel was investigated by strip drawing with bending and deep drawing of cups. The feasibility of dry metal forming by using a MMC tool surface could be demonstrated. Higher forming forces were required compared to a conventional bronze tool. However, adhesive wear of the tool could be reduced by applying MMC tool surface.

It can be concluded that it is appropriate to ablate the matrix of the MMC surface because there is no significant influence on the forming force. The contact area with the matrix can be reduced and thus adhesive wear in dry metal forming can be reduced by a plateau out of hard particles with high penetration.

\section{Acknowledgement}

This work was supported by Deutsche For-schungsgemeinschaft (DFG) within priority program SPP 1676 and the project Se1435/2-2.

\section{References}

1. P. Schmid, M. Liewald, AIP Conference Proceedings, 1383, 446-452 (2011)

2. B.-A. Behrens, S. Hübner, C. Sunderkötter, J. Knigge, K. Weilandt, K. Voges-Schwieger, Adv. Mat. Res., 22, 5-15 (2007)

3. K. Voges-Schwieger, S. Hübner, B.-A. Behrens, AIP Conf. Proc., 1353, 224-228 (2011)

4. N. Bay, E. Ceron, Advanced Materials Research, 966-967, 3-20 (2014)

5. P. Schmid, Advanced Materials Research, 769, 221228 (2013)
6. H. Freiße, A. Langebeck, H. Köhler, T. Seefeld, F. Vollertsen, Manufacturing Rev., 3, 13, 1-10 (2016)

7. N. Bay, A. Azushima, P. Groche, I. Ishibashi, M. Merklein, M. Morishita, T. Nakamura, S. Schmid, M. Yoshid, CIRP Ann. Manuf. Technol., 2, 760-780 (2010)

8. A. Almohallami, M. Arghavani, F. Böhmermann, H. Freiße, M. Herrmann, S.A. Mousavi, S. Schöler, P. Scholz, J. Tenner, M. Teller, G. Umlauf, D. Wulff, D. Yilkiran, H.J. Maier, Dry Met. Forming OAJ FMT 3, 90-94, (2017)

9. H. Hetzner, J. Koch, S. Tremmel, S. Wartzack, J. Manuf. Sci. Eng., 133, 1-11 (2011)

10. S. Kataoka, M. Murakawa, T. Aizawa, H. Ike, Surface Coating Techn., 177-178 582-590 (2004)

11. A. Pramanik, Trans. Nonferrous Met. Soc. China, 26, 348-358 (2016)

12. M. Cabeza, G. Castro, P. Merino, G. Pena, M. Roman, Surf. Interface Anal., 46, 861-864 (2014)

13. A. Grueninger, N. Weidlich, O. Meier, M. Deutschmann, Int. J. Microstructure and Materials Properties, 5, 2/3, 178-192 (2010)

14. H. Freiße, V. Hohenäcker, T. Seefeld, F. Vollertsen, Dry Met. Forming OAJ FMT, 1, 5-10 (2015)

15. H. Freiße, J. Vorholt, T. Seefeld, F. Vollertsen, Dry Met. Forming OAJ FMT, 3, 41-44 (2017)

16. E. Doege, B.-A. Behrens, Handbuch der Umformtechnik, Grundlagen, Technologien, Maschinen, 2, 324 (2010)

17. M.T. Farr, Zieh- und Stempelkantenradien beim Tiefziehen, Ph.D. thesis, University Stuttgart, 67 (2002)

18. H. Freiße, S. Schmidt, T. Seefeld, F. Vollertsen, Dry Met. Forming OAJ FMT, 4, 052-058 (2018)

19. H. Berns, Hartlegierungen und Hartverbundwerkstoffe (1998)

20. H.J. Meigh, Cast and Wrought Aluminium Bronzes, properties, processes and structure, 697 (2000) 